\title{
Where in America Are the Tech Firms Going and Why: An Exploratory Analysis of Site Selection Trends in the Information Technology Sector Based on Incentive Packages from 1980 to 2018
}

\author{
Nikolay Anguelov \\ University of Massachusetts, Dartmouth \\ Brenna Jewitt \\ University of Massachusetts, Dartmouth
}

\begin{abstract}
This paper tracks the location trends of information technology (IT) firms in the United States for the last 4 decades to identify commonalities in place-based recruitment subsidy policies and strategies. Utilizing the Good Jobs First Subsidy Tracker database, examined are: a) specific subsidy amounts; b) the type of subsidy, based on the different federal, state, and local options and c) the source of the subsidy funds, be it state, local or federal. Using ArcGIS programming, the analysis maps out the spatial clustering for new location deals of 421 IT facilities from 1981 to 2018. The trends in location choice are used to offer a typology of sub-industry relocation classifications, based on NAICS codes. These relocation flows are then evaluated for job creation outcomes. The findings indicate that fairly remote locations seem to consistently have lower number of jobs created at much higher dollar amounts spent per new job, as compared to metro areas. A clear trend of moving away from Silicon Valley emerges, where most new jobs are created in the Northeast and Canada, as a function of the most generous subsidy packages.
\end{abstract}

Keywords: incentives, subsidies, corporate welfare, information technology

\section{INTRODUCTION}

The American economy is in a changing era of industrialization through the quickly evolving technology and information industries, collectively referred to as the "new economy" (Atkinson, 2004). The Information and Telecommunications Technology sector, generally referred to as the IT sector is growing faster than any other sector, including manufacturing, finance, and professional services. According to the latest numbers from Cyberstate.org, the IT sector accounts for over $10 \%$ of America's economic output, employing 11.8 million. ${ }^{1}$

In an effort to attract the IT sector, economic developers design specific to the sector incentive packages of subsidies for the recruitment and retention of new economy firms. This dynamic is much studied and subject to continuous refinement in inquiry. That is the case because the assumption is that tech firms have high value creating job potential and generate positive knowledge spillovers for other local industries (Díez-Vial \& Fernández-Olmos, 2015; Isaksson, Simeth, \& Seifert, 2016). The most often cited beneficial outcomes of such spillovers include increasing entrepreneurial and innovation rates, 
providing procurement options to local suppliers, and attracting human capital. In the context of previous findings on these dynamics, this paper tracks the location trends of the IT sector in the last 4 decades to identify commonalities in attractiveness strategies. Utilizing the Good Jobs First Subsidy Tracker database, we focus on a) subsidy amount; b) type - the 14 different state and local options and 5 federal options and c) source - state, local or federal. Parsing out IT firms from the Subsidy Tracker records for 607,000 deals, we compile a list of 421 deals, based on data availability. Using ArcGIS programming, we offer a typology of sub-industry classifications based on NAICS codes, to map out the job creation outcomes from those deals.

The results indicate the emergence and growth of IT clusters with the following commonalities in terms of subsidies and the associated new jobs created at the municipal level:

1. Most jobs created are in the Northeast US and Canada and they are congruent with the most generous packages

2. Tax credit/rebate is the most common subsidy awarded

3. The sub-industrial growth is strongest in software and data analytics

4. A clear trend of moving away from Silicon Valley emerges in the last decade, with new deals clustering in Boston, Washington, D.C., Denver and the greater Chicago area

5. Subsidies by the state are most prevalent with county-level subsidies coming second, mostly in denser metro areas

The results suggest that, although most IT jobs have been created in the Northeast, the number of jobs created in relation to the dollar amount of the incentive packages are highest in Los Angeles and the greater Chicago area. The fairly remote locations seem to consistently have low number of jobs created at much higher dollar amounts spent per new job, as compared to the metro areas.

\section{PREVIOUS FINDINGS}

The economic cycles of fast-paced technology adoption and their impact on urban and regional development around the world have been the focus of analysis in the new economy from across disciplines (Belderbos, Lykogianni, \& Veugelers, 2008; Atkinson, 2004; Venables, 2006). Specifically, the creation and growth of technology cluster hubs, best exemplified by Silicon Valley, has been the subject of analysis on the socio-economic characteristics that follow such hubs (Kogut, 2003; Pellow \& Park, 2002; Saxenian, 1983, 1990). Today, Silicon Valley is the home to tech market leaders such as Google, Facebook, and Apple. The literature on knowledge-intensive firm clusters, comprising works from economics, political economy, and industrial geography, sums up the reasons for IT clustering as linked to knowledge spillovers that benefit inter-firm relations in close proximity (Belderbos, Lykogianni, \& Veugelers, 2008); Díez-Vial \& Fernández-Olmos, 2015; Klier \& Testa, 2002; Martin, 2010; Simmie \& Martin, 2010; Venables, 2006). Innovation in production and operations management, learning, and "coopetition" - competing while collaborating - are among the main reasons to seek presence in IT clusters, such as Silicon Valley.

Yet, in recent years, analysts have noted a trend of influential tech firms expanding outside Silicon Valley, mainly to mid-sized cities or even rural American areas (Byrnes \& Cowan, 2007; Glass, 2011; Gura, 2012; Johnson, 2015; Miller, 2013). In September of 2017, Amazon released a Request for Proposals (RFP) for its second headquarters - Amazon Headquarters 2 (HQ2) ${ }^{2}$ - indicating a willingness to consider many municipalities outside of established tech clusters. The RFP promised to create a new "tech campus" that would create 50,000 full time jobs with the average salary being $\$ 100,000$. Cities all over the United States rushed to respond and make a case for why their city was qualified to house the new Amazon HQ2.

Major large cities, including Boston, San Francisco, Los Angeles, and New York City participated in the submission, ${ }^{3}$ along with many mid-sized American cities, such as Detroit, Memphis, Baltimore, and Minneapolis. All RFPs promised Amazon large tax breaks and/or place-based incentive packages in their bids. $^{4}$ The body of research on such incentive packages is large, diverse in terms of industrial and community characteristics, and inconclusive in terms of cost and benefits. Since the 1990s, as works on 
decreasing spatial costs in production noted that technology is changing the incentives in strategic site selection (Bollinger \& Ihlanfeldt, 2003; Hanson \& Rohlin, 2011; Holloway \& Wheeler, 1991; Venables, 2006), analysts and scholars have studied the trend of diffusion outside of traditional business district hubs. For example, Klier and Testa (2002) find that in the 1990s New York City was slowly losing its high rank as being headquarter dense to smaller metropolitan areas with a population between $\$ 1$ to $\$ 2$ million. The authors posit that high-tech companies have been clustering in areas such as Raleigh, San Jose, and Austin. The findings also suggest that the relocation trend resulted in economic and social changes, such as population growth and increasing market competition. In relation, Koven and Koven (2018) compare case studies of well-known American cities that have gone through distinguishable periods of growth, rejuvenation, or decline - Austin, Boston, Minneapolis, and Detroit. Per each, the authors analyze factors that either have tended to contribute to growth or economic health - trade routes, natural resources, human capital, universities / institutions, public officials, and prominent business - or factors that have led to decline - "oppressive" taxes, ethnic intolerance, failure to adpat to new technology, "ossified" political structures. In terms of firm-level analysis of place-based decisions, the authors explain that not only do current economic dynamics matter, but also a city's history is an important factor. Other distinctive factors include transportation costs, labor costs, labor unionization, proximity to markets, suppliers, resources, and other facilities, and quality of life (attracting the worker), as being direct considerations.

These factors are well-outlined in previous works on site selection trends, which examine the importance of geography, quality of life, even social construction and culture (Barkley \& Henry, 1997; Bollinger \& Ihlanfeldt, 2003; Florida, 2019; Garnsey \& McGlade, 2006; Hill, Wial, \& Wolman, 2008; Loveman \& Gabarro, 1991; Martinez-Fernandez et al. 2012). The paradoxes that emerge from such analysis is in the fact that in the new economy, as distance collaboration increases, outsourcing and outcontracting in production and services rises, and strategic markets change, a community's business attractiveness features can change as a function of policy. The policy being the incentivizing of firms' location choices through industrial recruitment and retention (Faulk, 2002; Hicks \& LaFaive, 2011; Hickey, 2013; Pries, 2006; Walker \& Greenstreet, 1991). Industrial recruitment has been subject to criticism for creating race-to-the-bottom perverse incentives (Davis et al., 2015; Greenstone \& Moretti, 2003; Story, 2012) that erode local tax bases (Barkley \& Henry, 1997; Gropp \& Kostial, 2000; Mattera et al., 2012).

Industrial recruitment has also been criticized as having a negative impact on the competitiveness of small and emerging firms. Specific to the United States, LeRoy et al. (2015) review 4,200 economic development recruitment "packages," as is the term, of incentives across 14 states in analyzing the difference of awarding packages to small and medium-size enterprises (SMEs). The study finds that $80 \%$ to $96 \%$ of incentive shares are awarded to large companies, at an estimated average of $\$ 3.2$ billion each year. LeRoy et al. (2015) is among the first works that provide an in-depth look not only at the economic geography of incentives, but also at the conflicts they may create. The analysis indicates that small business owners posit their operations would specifically benefit from incentives in workforce development, such as training and retention public-private partnership collaborations in subsidizing college-level courses for workers and/or vocational training initiatives. Yet, most incentives are in the form of direct monetary concessions, such as tax breaks, and abatement of utility rates, which just lower the fixed costs of production for firms (Prillaman \& Meier, 2014; Sullivan \& Green, 1999; Wilson, 1996; Zee, Stotsky, \& Ley, 2002). Since those fixed costs are subject to economies of scale, when awarded to large firms, incentives only help larger firms become even more price-competitive in relation to smaller businesses, increasing their ability to crowd-out incoming competitors. The purpose of incentives is to "correct market imperfections" (LeRoy et al., 2015: 3). However, when they are disproportionately awarded to big-businesses, corrections are only made in a portion of the market, if at all.

In a related study from Good Jobs First, a leading equitable ${ }^{5}$ economic development think tank in Washington, DC, Tarczynska (2016), offers details of specific well-known technology companies that have taken advantage of subsidies for their data centers, such as Google, Microsoft, Facebook, Amazon Services, and Apple. Specifically, 27 states have programs dedicated to data center incentive packages. 
The report describes these companies' data centers relocation announcements as an outcome of successful "bidding wars" (Tarczynska, 2016: 2). The numbers of such bids add up to over $\$ 2$ billion in subsidies, which on average amount to $\$ 1.95$ million per each newly created job. In congruence with the findings of LeRoy et al. (2015) that the most generous subsidies go to the large firms, Tarczynska (2016) posits that Apple's data center incentive deals equal an outstanding \$6.4 million per newly created job. Analyzing the details of data center deals, subsidizing electricity and water consumption is a common theme, as their costs comprise 70 to 80 percent of data center consumption costs (Tarczynska, 2016: 4). The implication is that labor costs are 20 to 30 percent of average fixed costs. A size effect is also noted at the regional level. Large states, and in them locales least-prone to flooding and/or are seismically stable, specifically California, Texas, and New York have the highest square footage of data centers. Yet, despite size, each has had a minor role in creating employment opportunities, averaging 3-50 jobs (Tarczynska, 2016: 15).

In summary, the logical question is echoed once again: Why are state governments subsidizing big businesses which have the resources to be self-sufficient? Research has shown that it is for amassing political capital (Gordon, Hafer, \& Landa, 2007; Francia et al., 2003; Jensen et al., 2014; Jensen, Malesky, \&Walsh, 2015; Jensen \& Malesky, 2018). The findings indicate that politicians facing electoral pressures tend to be more "generous" in incentive concessions, especially around municipal elections.

At the state level, evidence also suggests incentives to have limited market benefits that can lead to growth in economic development. Specifically, Prillaman and Meier (2014) examine state business taxation between 1977 and 2005, with a focus on factors of economic performance that include income and labor market growth, poverty rate, and rates of entry/exit of new businesses. The findings indicate that state tax incentives have minimal influence on business relocation or site selection. The authors note that despite this fact, state policy makers continue to "enthusiastically" use these techniques. Jensen et al. (2014) explain that the reasons for such "enthusiasm" lie in the political will to show proactivity to address economic decline. The authors find that tax incentives are often given by fiscally struggling states, even when politicians have access to infromation on the ineffectiveness of incentive policies. The main reason is that voters side with the officials who have pushed through incentive deals. This political favoritism stems from hope and promise. Politicians promise that new incentive deals create jobs and voters like that promise. Despite evidence to the contrary, it is the demonstration of political action that is rewarded.

Research continues to analyze the magnitude of this discrepency in terms of concessions and the fulfillment of the promise of new economic growth. Among such works is Greenstone and Moretti (2003) who examine economic impact effects at the county level of a successful "bidder" that "wins" a site selection race. The economic impacts of the location of a new facility to the "winning" county are compared to the plants' county-level impacts of the top two contenders that lost the bid. The results indicate that economic growth patterns remain unchanged, save for a modest increase in labor earnings in the winning county of $1.1 \%$ and a $10.2 \%$ increase in property values. Discussing the case of BMW's creation of its first production complex in America in Greenville-Spartanburg, South Carolina in 1982, the authors explain that the company prioritized low union density, qualified workers, numerous global firms with presence in the area, as well as a quality transportation infrastructure. BMW also negotiated "special access" to local utilities. Follow-up investigations on what this "special access" entails suggest that it is concessions of local utility providers on payment of water, sewer, and electric rates (Anguelov, 2014; Karayel, 2017). This fact, congruent with the findings of Tarczynska (2016) that up to 80 percent of operating costs in modern data centers are for water and electricity, suggests that utility costs are an important bargaining chip in site-selection negotiations because they can be lowered by local governments. Not much other empirical work is there on this dynamic, mainly due to the fact that most incentive package specifics are not publicly available (Bartik, 2018; Jensen, 2017a,b,c). Furthermore, they are continuously renegotiated (Thomas, 2010).

In summation, investigation of who benefits from "place-based" industrial recruitment policies, as is the emerging phrase, keeps finding little in the context of equitable benefits that accrue to citizens of specific municipalities. Typically, when subsidies are given for economic development purposes, job 
creation is the main motivation for buy-in. Kline and Moretti (2014) focus on successful outcomes of subsidies when jobs are created, in addition to the jobs per-se. The authors identify five areas that have been positively affected by placed-based incentives - public goods, agglomerations economies, labor market frictions, credit constraints, and/or pre-existing distortions, meaning monopolistic inefficiencies. Yet, these outcomes as subject to finer cost-benefit queries, which define localized public goods, for example. A park built by a firm for which it gets to claim community-investment credits that it can leverage against its property tax burden, can hardly be considered a public good in the pure sense of the definition. In relation, creating labor market frictions may be good for local business, as it increases competition in the labor pool, but it is because the new facility attracts labor from outside the municipality, leading to the concept of "flooding the labor pool." A flooded labor pool results in lower financial compensation - both in salaries and other benefits for workers - as well as in negative impacts on labor organization (Barnet, 1996). That is the reason why Greenstone and Moretti (2003) specify that lower unionization was essential for BMW's choice to locate in South Carolina.

The issues of equitable job creation as a function on incentives is well reflected in the reports of Good Jobs First. ${ }^{6}$ The organization has been tracking the scope and type of incentives of over 607,000 deals throughout the United States since the 1980s. The mission of the organization states that: "given the enormous sums involved, taxpayers and public officials need and deserve better information" as tax payer money and property tax is used for incentive pay-offs in corporate welfare - the other term often used to give a negative connotation to industrial recruitment. Some of the amount estimates defy any reasonable per-job benefit-cost analysis logic. For example, Materra et al. (2013: 13) analyze over \$64 billion worth of deals, starting with Volkswagen's expansion in Pennsylvania's in 1970. Comparing the amount of documented jobs created in response to these deals, the average cost per job is $\$ 456,000$. Some of the well-known companies that have taken advantage of these packages are Exxon Mobil, Boeing, Airbus, Citigroup, GE, Amazon, Apple, Intel, and Samsung.

Despite the criticism, incentives are here to stay. They are politically popular and have become the primary tools of economic development policy (Faulk, 2002). To that effect, empirical efforts are underway to quantify their localized impact in direct costs. This paper adds toward that goal with a spatial approach by mapping out the location and re-location of information technology firms as a function of incentives.

\section{DATA AND METHODS}

We employed a contextual descriptive analysis of the site location trends of the information technology sector companies by analyzing documented incentive package deals between the years of 1981 and 2018, utilizing the Good Jobs First Subsidy Tracker data base (Mattera, Tarczynska, \& LeRoy, 2013). Parsing out the IT sector specifically, yields a dataset of 421 deals from that time frame. The list is included as Appendix 1. We codify the deals based on received site-based incentive packages from either local or state agencies. We focus on deals as the unit of analysis, rather than company, because many of the companies are listed multiple times, as it is common for firms to acquired multiple packages at varying locations. The deals codified by: a) company name, b) location, c) sub-industry description, d) year the subsidy was awarded, e) the dollar amount of the deal in U.S. dollars, f) the level of government and agency that awarded this package, g) the type of incentive, and $h$ ) the number of jobs created.

Polyline data associated with geographical boundaries, known as TIGER/Line ID (TLID) was then coded and added to this information on a county level. Ideally, such analysis would be best conducted on the city/municipal level. However, the TLID codes are tracked per areas that have a population of 2,000 people or more. Not all boundaries of municipalities that supplied incentive packages were available, as some have populations under 2,000 people.

After merging the TLID data with the Subsidy Tracker data, the set was then uploaded into the ArcGIS program - a geographic information system that allows for the analysis of data through the creation of maps. To visually review the trends of technology industry incentive packages, maps were created to compare and represent the following information regarding each incentive: 
a) per Location

b) per Year (codified into decades - 1980s, 1990s, 2000s, 2010s)

c) per Subsidy Amount (dot size is proportional to subsidy amount)

d) per Subsidy Source (state or local)

e) per Subsidy Type

f) per Sub-Industry (description or NAICS code)

g) per Jobs Created (dot size proportional to number of jobs created)

There are two major limitations in the analysis. First, as is often the case with incentives packages, specific amount and job numbers per deal are not publicly released (Mattera, Tarczynska, \& LeRoy, 2013). For deals where number of jobs created is missing, used instead is "projected number of jobs." This is a very serious limitation because it is at the core of the issue of unfulfilled promises. Future research can focus on the gap between promised and materialized new jobs. The second limitation is with the geographical specifications. Subsidy Tracker compiles deal data on a city or municipal level. The information often has the exact street address of the company receiving the incentive package. However, when translating this information in the ArcGIS program, polyline boundaries were needed to spatially map locations. As previously mentioned, these polylines are usually only given to cities that have populations of over about 2,000 people. Due to some of the data centers and "server farms," as is the emerging phrase, locating in remote, sparsely populated locales, those municipalities could not be bounded by a municipal level polyline. Therefore, we had to aggregate locales from the suburb to the county level.

\section{FINDINGS AND ANALYSIS}

The spatial maps are presented below in order of deals made: A) per Location, B) per Decade, C) per Subsidy Amount, D) per Subsidy Source, E) per Subsidy Type, and F) per Sub-Industry

\section{FIGURE 1}

\section{SPATIAL MAP A: CLUSTERS OF DEALS PER LOCATION}

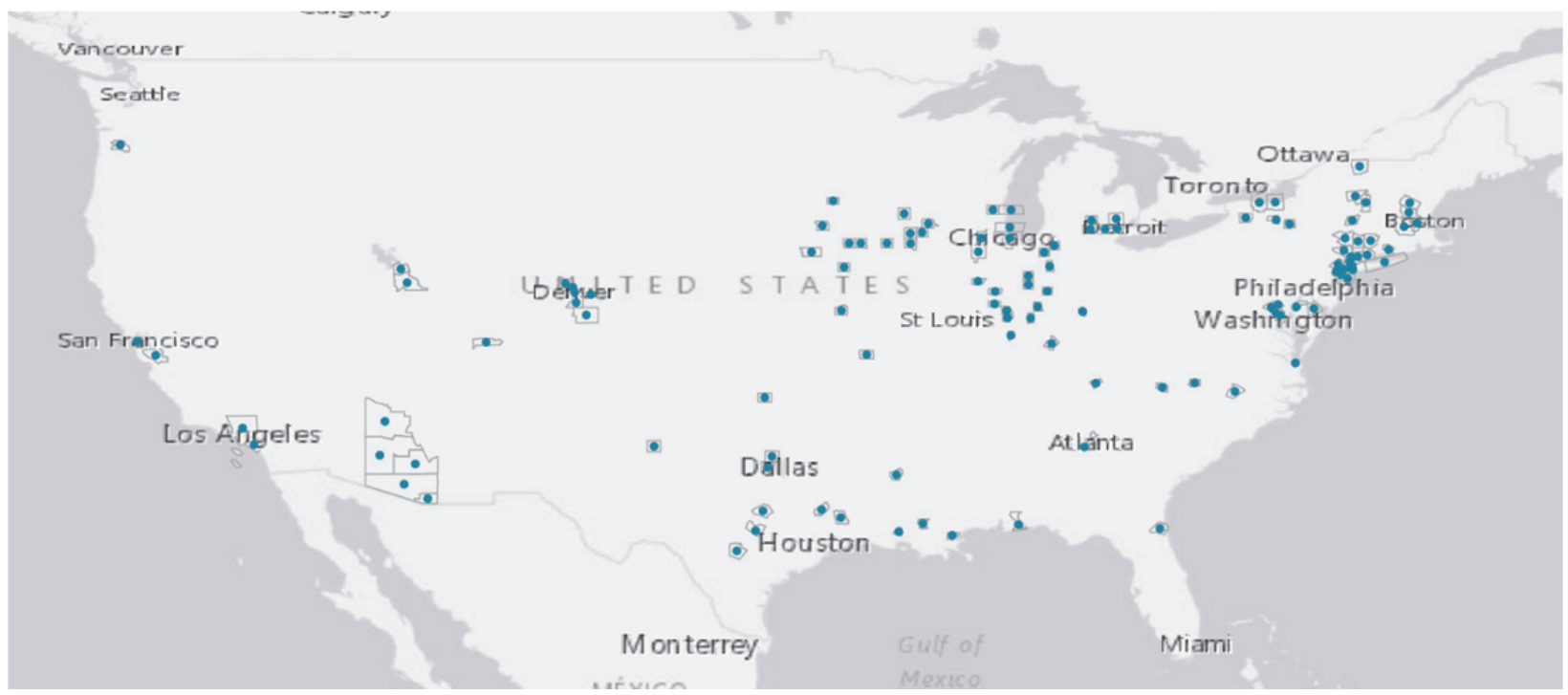


FIGURE 2

\section{SPATIAL MAP B: CLUSTERS OF DEALS PER DECADE}

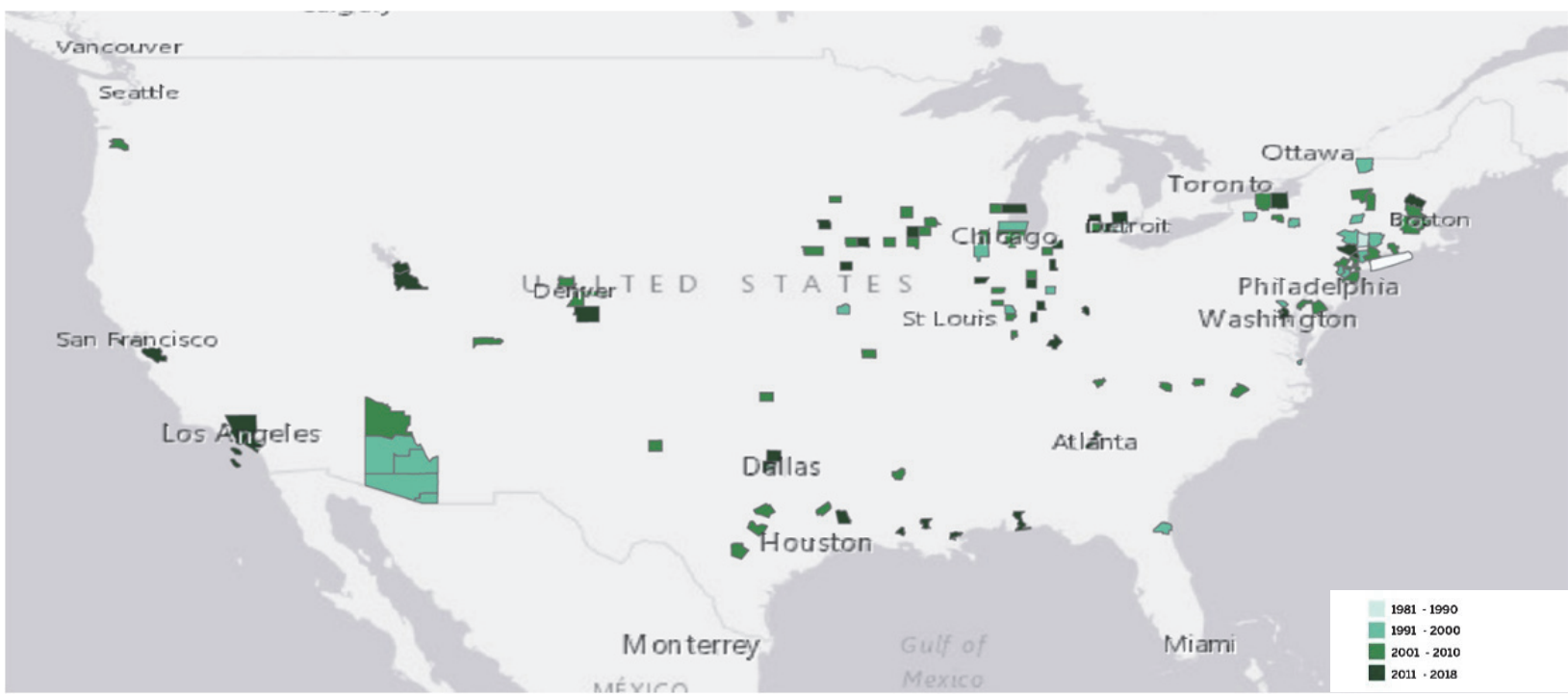

FIGURE 3

SPATIAL MAP C: CLUSTERS OF DEALS PER SUBSIDY AMOUNT

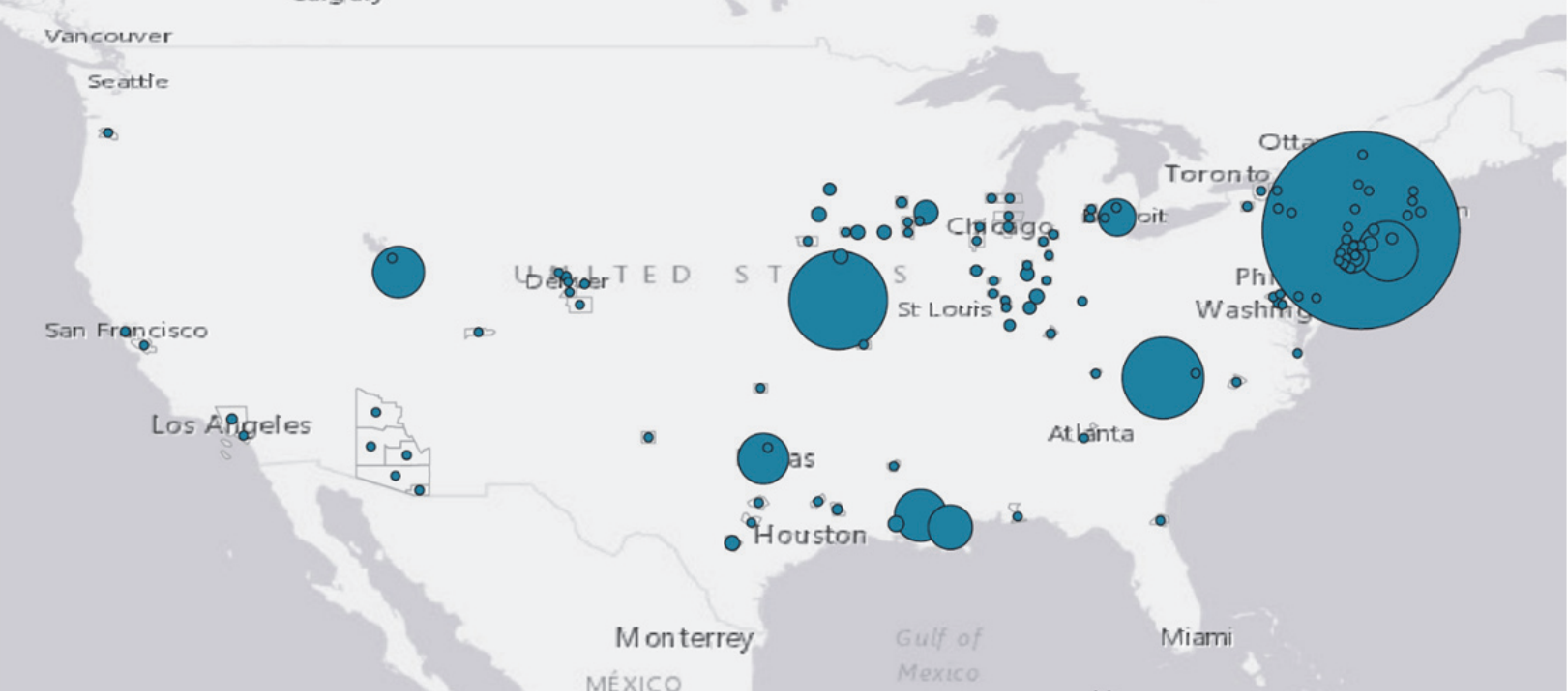


FIGURE 4

\section{SPATIAL MAP D: CLUSTERS OF DEALS PER SUBSIDY SOURCE} (LOCAL, STATE, OR FEDERAL)

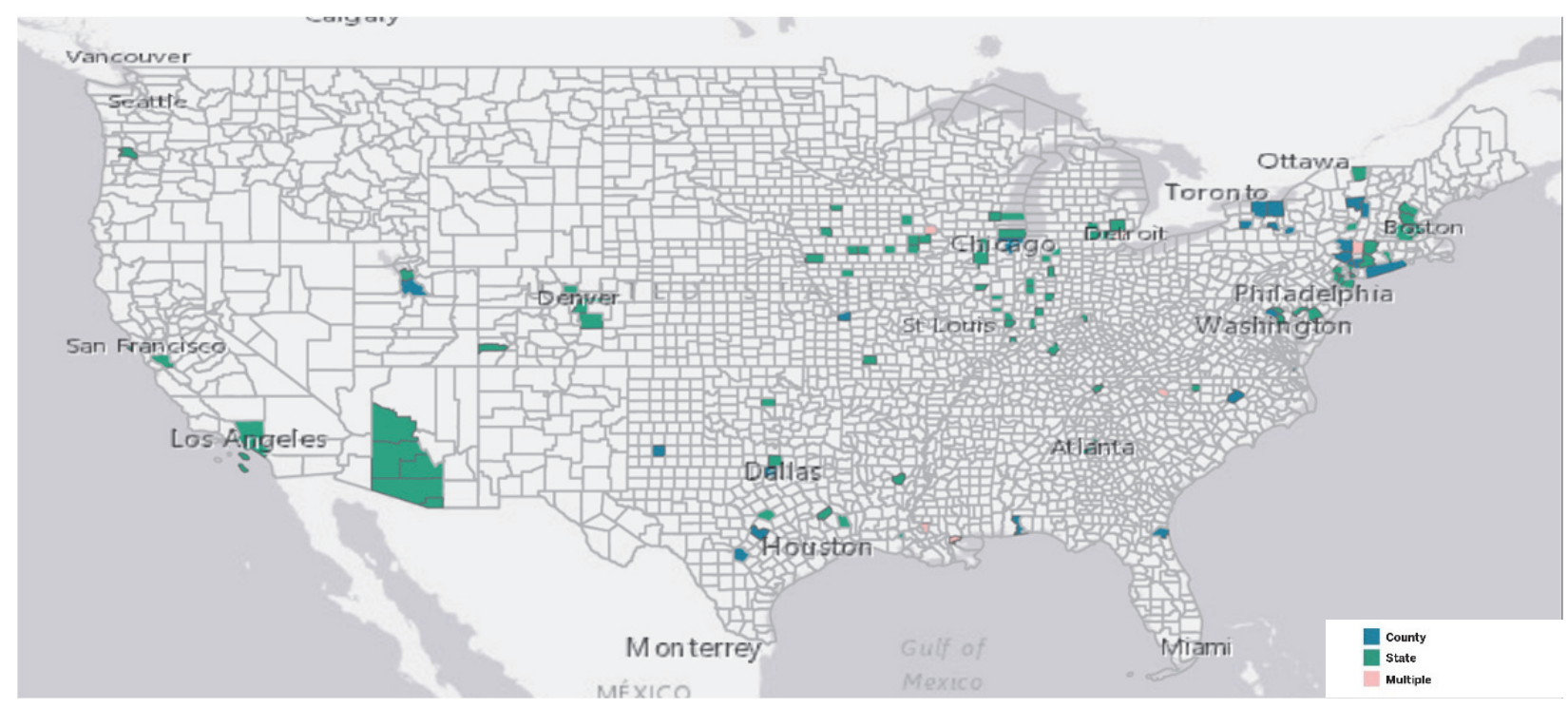

FIGURE 5

SPATIAL MAP E: CLUSTERS OF DEALS PER SUBSIDY TYPE

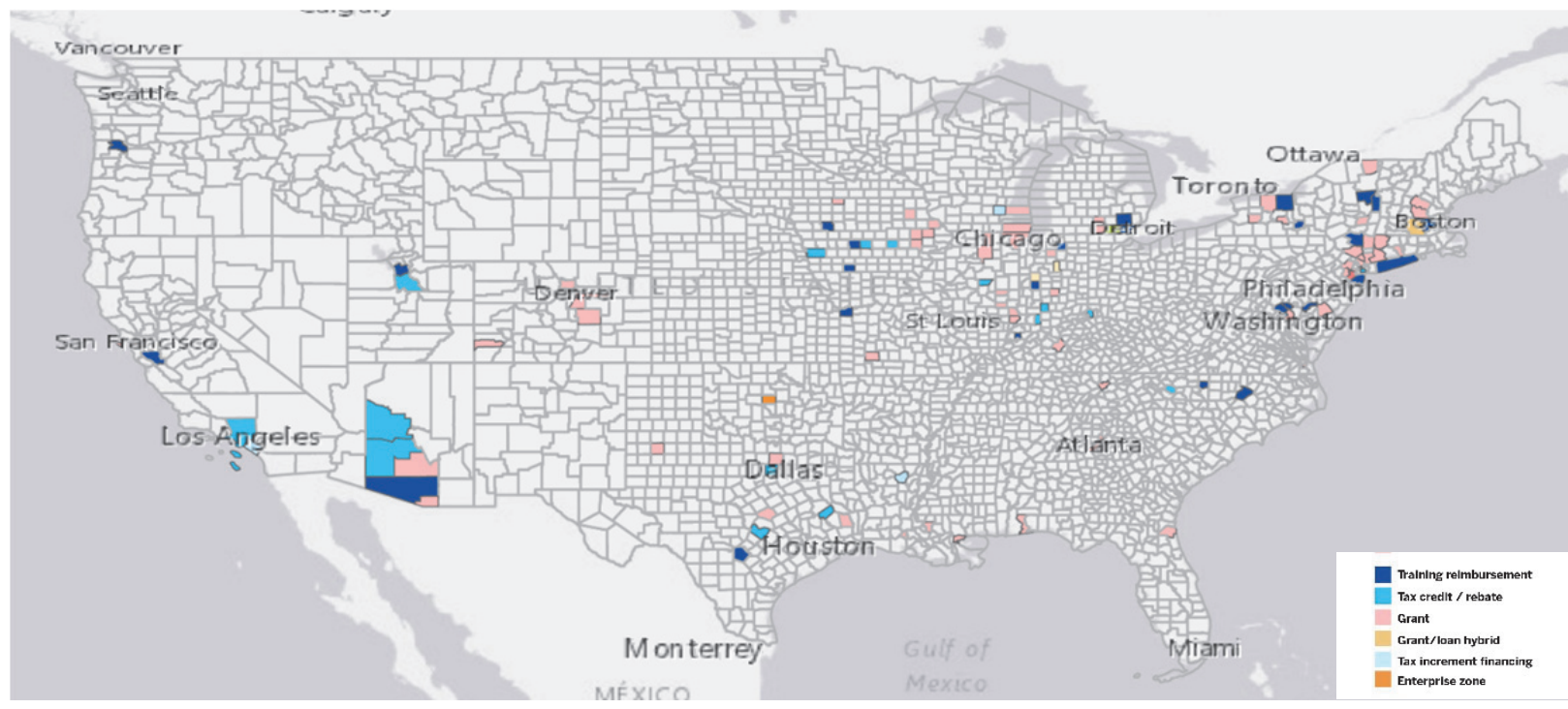


FIGURE 6

\section{SPATIAL MAP F: CLUSTERS OF DEALS PER SUB-INDUSTRY CATEGORY}

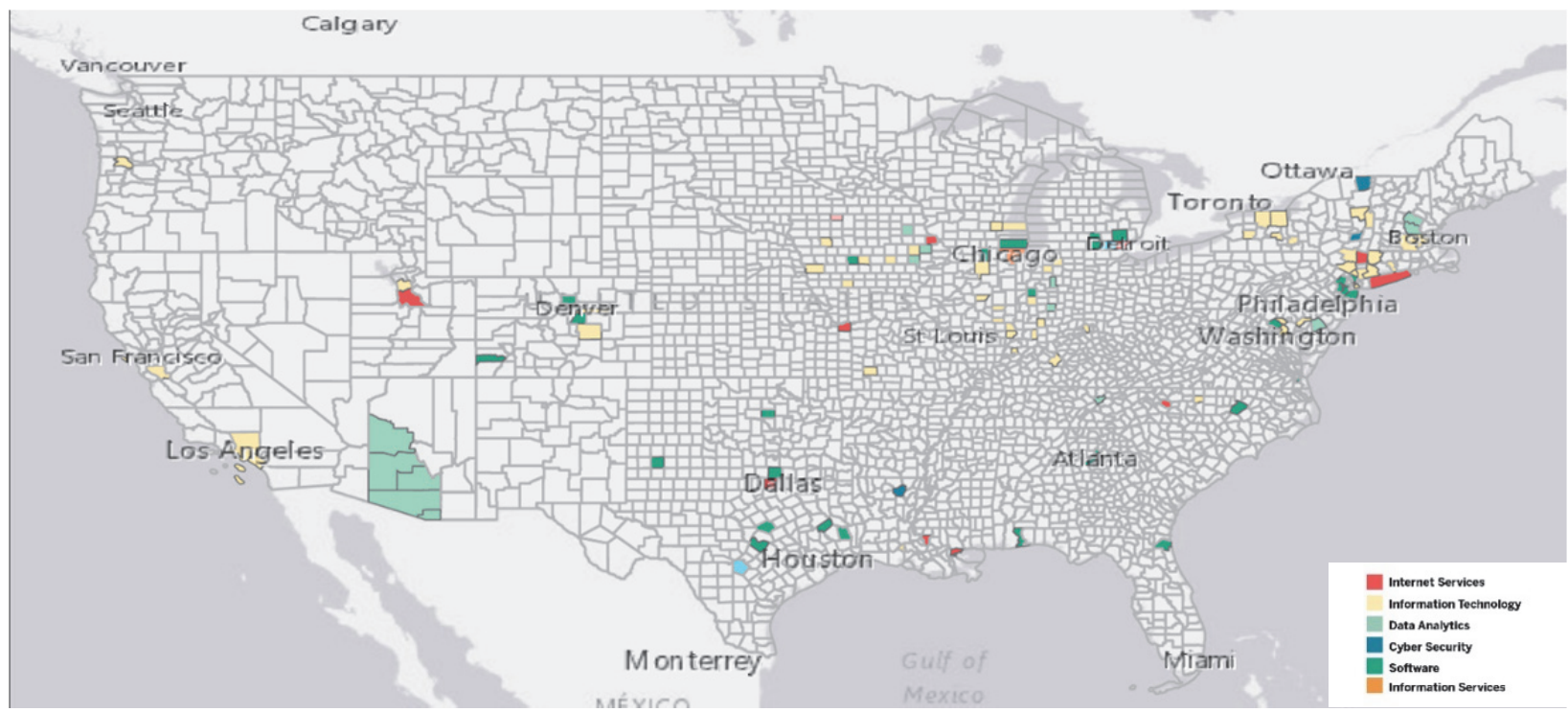

\section{FIGURE 7}

\section{SPATIAL MAP G: CLUSTERS OF DEALS PER JOBS CREATED}

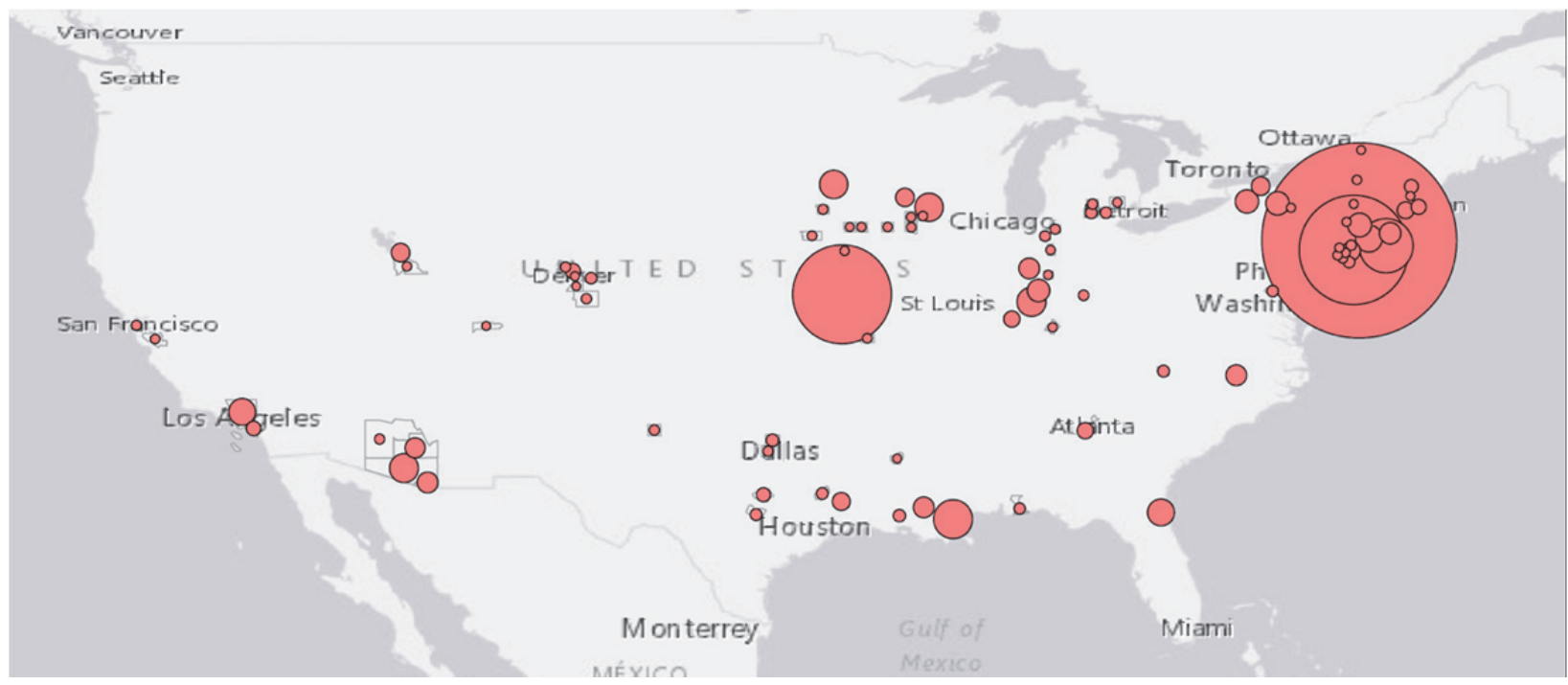

In relation to the broad research question here of whether geographic patterns of IT clustering are emerging, the following summative points offer supporting evidence to that effect:

1. The quantity of information technology companies awarded subsidy packages substantially increases in 2005 and again in 2012, staying quite consistent the years in-between. Limited data is available from 2016 and on as the subsidy dollar amounts are tracked at end of year based on how much money was given to each company.

2. Florida, New York, Missouri, Iowa, and North Carolina seem to have substantially more subsidy deals in relation to the number of firms that have received incentive packages.

3. Missouri and New York have provided more local subsidy packages, while North Carolina leads in state given subsidies. 
4. "Tax credit / rebate" is by far the most common type of subsidy awarded throughout all states.

5. The sub-industry description of "information technology" and "software" are the most common throughout the data.

As seen in spatial maps, the North-East contains a relatively denser proportion of deals in terms of both quantity and vale amounts. From Ottawa, Canada, through the Greater Boston and New York corridor down to the Washington DC area, it is evidence that a large cluster is emerging in the Northeast, as compared to Silicon Valley. A second, more dispersed cluster is evident in the Chicago, St. Lewis, area, reaching out westward into the Dakotas and Minnesota and Wisconsin. Denver, Huston and Dallas are next, followed by Phoenix and Tucson. Overall, around 300 of all 421 deals examined are based on incentive packages from "state" financial support, while 112 codified as supported by "local level" funding. The remaining deals are based on incentive packages from "multiple sources." The most common type of incentive is a "tax credit or rebate." It is defined as a program that combines tax credits and/or rebates with state or local grants (Mattera, Tarczynska, \& LeRoy, 2013).

Company sectors labeled as having a sub-industry of "information technology" are the dominant industrial classification, receiving about half of the quantity of all awarded incentives. The awarding agencies vary greatly amongst governor offices, tax commissioners, economic development agencies, job training funds, commerce authorities, or local tax incremental financing (TIF) groups, which are either municipal governments, economic development agencies and/or redevelopment authorities, depending on which governing body oversees local property tax management (Pacewicz, 2012). In this very even mix of awarding bodies, a definite outlier emerges. Although most financing is linked to state and local subsidy sources, a federal source is first on the list here - the Department of Revenue - with 92 appearances in our data set. It must also be noted, that almost all of these incentive deals occurred in the Winston-Salem County of North Carolina. It is beyond the scope of this study to delve into this fact in detail. Further inquiry is warranted because this fact may be evidence of an informal industrial policy at the federal level, something the American government vows to not support.

The spatial analysis here also reveals commonalities in regional features of "attractiveness." We offer the following typology in the context of prior literature that includes studies from around the world, as well as the United States. In the global regional economic development literature, which comes from several disciplines, place-based incentive trends are of much interest. In the context of findings in seminal works from the literature at large, the following list outlines the most-commonly considered priorities in American tech industry site selection:

- Cheap Electricity / Water (Tarczynska, 2016; Koven \& Koven, 2018)

- Seismically Stable / Natural Resources (Pendall, Foster, \& Cowell, 2010; Rose \& Liao, 2005; Tarczynska, 2016)

- Trade Routes / Transporation Costs (Garnsey \& McGlade, 2006; Hill, Wial, \& Wolman, 2008; Koven \& Koven, 2018)

- Degree of Competition / Knowledge Spillover (Belderbos, Lykogianni, \& Veugelers, 2008; Klier \& Testa, 2002; Kline \& Moretti, 2014; Kogut, 2003)

- Network of Firms / Concentrating Resources (Belderbos, Lykogianni, \& Veugelers, 2008; Markle \& Shackelford, 2014; Martinez-Fernandez et al., 2012)

- Infrastructure and Assets (Aguezzoul, 2014; Martinez-Fernandez et al., 2012)

- Population Skills / Human Capital (Bollinger \& Ihlanfeldt, 2003; Garnsey \& McGlade, 2006; Loveman \& Gabarro, 1991; Martinez-Fernandez et al., 2012)

- Universities / Institutions (Briguglio et al., 2006; Kogut, 2003; Koven \& Koven, 2018)

- Quality of Life / Recruiting (Koven \& Koven, 2018; Venables, 2006)

In summary, we conclude that there are clear hot spots for technology location selections. There is greater quantity of new location deals on the East coast, from Boston to Washington, D.C., to be followed by the Midwest, i.e., the greater Chicago area and Denver, Colorado. Very little of the same is occurring in the well-known tech hub, Silicon Valley. A detailed analysis on this point is needed because this fact 
may indicate not that new enterprise is not forming or locating to the Valley, but rather that monetary incentives are not needed for those deals. The knowledge spillovers of the Silicon Valley cluster may be important enough and local governments would not and do not engage in industrial recruitment competition as they do in other regions of America.

In this competition for deals, new jobs are the ultimate goal of local governments. Therefore, we treat new job creation as a measure of success of place-based incentive policies, based on the number of jobs created in comparison to the dollar amount of the incentive package. From the spatial maps presented here, a first-glance impression would suggest that considerably more jobs are created in the clusters on the East Coast. However, when controlling for the amount of incentive dollars associated with each job, maps $\mathrm{C}$ and $\mathrm{G}$ indicate that Los Angeles and the greater Chicago area are more successful in capturing incentives-to-new-jobs value.

The results also indicate that the fairly remote, in terms of being away from major cities and other clusters, locales consistently tend to end up creating a lower number of jobs at higher dollar amounts spent per each. This fact could be capturing a factor discussed in professional and trade press but not yet well-addressed by the academy of the emergence of "data and server farms." These facilities, which employ relatively few workers, are attracted to fairly remote areas for direct cost-cutting reasons. The trend is reminiscent of the "rural stage of dispersion" discussed in the literature on the product life cycle (Atkinson, 2004; Klepper, 1996; Vernon, 1979). It follows the innovation stage, which generally occurs in a large metro area, when enterprises scale up production volumes for mass-market supply, and move production facilities to rural areas. Is the same dynamic emerging in modern IT? It might be. Spatial Map B indicates that fairly recent deals - from 2011 to 2018 - still strongly clustered in Silicon Valley and large cities. Furthermore, Map F - offering the sub-industry granulation - indicates that those locales were favorited by "technology" firms in comparison to "software." "Software" is associated with component manufacturing, therefore, within the IT sector it is relatively more labor intensive. Further analysis on incidence and type of company and service and/or production is needed.

The results also show a strong size correlation between the mapped number of newly created jobs and the amount and/or value of incentive packages. Larger incentive packages create more jobs, yet it is unclear if all incentive packages create enough jobs to offset their concessions. The results here do indicate a significant increase in the creation of over 1,000 jobs after deals reach the $\$ 7$ million incentive package price tag.

Another trend is also evident. We observe cluster forming in a path-dependent manner. The data indicate that, especially in the last decade, technology companies may be moving or setting up new presence away from Silicon Valley to other metropolitan areas such as the Chicago, Denver, Boston, New York and Washington, DC, but mainly when there was an established tech company in the area of at least ten years. This trend has similarities with the concept of "satellite cluster" in Markusen (1996) typology of industrial clusters. Future studies can analyze the knowledge sourcing component in IT entrepreneurship of the relationship between new arrivals and local well-established industrial partners.

\section{CONCLUSION AND IMPLICATIONS}

The geo-spatial analysis of site-selection trends of IT firms performed here indicate a trend to geographically "hug" inner metropolitain areas. While this fact is well-reflected in previous research, our results provide a granulation in site selection preferences. We observe that medium size metropolitan areas are preferred by sales centers specializing in data commerce. On the other hand, manufacturing centers, producing IT components are clustering in less population-dense areas. We note a rise in the location of such facilities to rural areas. This fact could be due to advances in communication and production that allow for detaching of manufacturing, sales, and research departments. Future research can focus in such hypothetical detachment in the context of outcontracting. It would help policy makers better understand the needs of companies, as well as their operations. This understanding can better inform incentive design. 
As with much prior research, our analysis notes a disproportionate relationship between the generocity of incentives and the jobs they create. The results show that fairly generous incentives packages are given in actual IT industrial clusters. Although the clusters are metro-area specific, the most commonly awarded type of incentives are not municipla but state-funded. This fact could be linked to the large emounts of such packages, which are beyond the funding capacity even of large metro areas. Those metro area "hugging" clusters have grown in the past 40 years mainly on the East Coast, in locales that have historically been manufacturing industrial hubs. The implication is that as these locales are moving into the new, knowledge-intensive economy, they are more aggressively competing for new IT facilities.

Question still remains: Would IT firms choose such locales that are "diverse," in terms of human resources and finance, yet "stable," in terms of infrastructure and economic geography? Or are incentives the new path-dependent state in economic development? Has the process of awarding incentives become a policy? It is imperative to continue analyzing such questions in the context of productivity gains from technology itself. If incentives are justified by their promise to create jobs, when productivity growth is assocaited with fewer jobs, what is the actual justification for incentive-based industrial recruitment competition?

One thing the bid for Amazon's new headquarters showed policy makers is that the firm had specific needs, which at first were not well-outlined in the RFP for incentives. As a result, big and small cities, in strategic hot spots and in declining regions, raced to attract Amazon with incentives. There was a wellcovered backlash against the incentives offered, the promises of jobs that were nebulous, and the actual need of incentives per-se when negotiating site selection options with a firm such as Amazon. In the end, the firm chose Arlington, Va after pulling out of New York City because of the political and communal outcry against the generous incentives NYC and the states offered (Stevens, Vielkind, \& Honan, 2019).

In Virgiania, when all is finalized, the new facility would cost the state over half a billion dollars in tax breaks, direct cash payments, and, as Wikipedia puts it: "other incentives." This amount is decidedly lower than the estimated $\$ 3$ billion New York offered. Analysis of why is largely absent, however it merits attention. Why would Amazon settle for a much less generious deal? Was this fact an outcome of the public outcry against coroporate welfare, as the media rightfully portrayed the bidding process with high publicity? When big incentive deals are subject to such high level of public attention, is a checks and balances process occurring that can have price discovery and correction features of incentive amounts? Much of the literature deals with a fundamental question on why municipalities offer very generious incentives in return for benefits that are often sub-par.

There are no clear answers to that question because few analysts can quantify what is too much to offer, especially in the context of non-incentive benefits that firms seek. In the case of Amazon, when the public outcry about incentives reached national political prominance, Amazon skillfully responded with a justification of its final choice of location in Northern Virginia with a reason that was not contingent on specific incentive amounts. The media, at large, reported that reason to be that the DC metro area attracts talent and therefore, offers an uniquely creative labor pool. This labor pool has already helped establish the area as a dynamic IT cluster. Just like the majority of 421 IT firms analyzed here, Amazon chose a municipality on the East Coast, "hugging" a major metro area, where not one, but several major IT firms have established strong presence, including Datatel, Accenture, and IBM, and where incentive packages, while fairly generous, are mainly funded by the state. These are the major trends that our analysis reveals in site-selection redirection of IT companies from Silicon Valley to the East Coast. Amazon's HQ2 choice to expand in Arlington, VA is congruent with the results in this study. 


\section{ENDNOTES}

1. Estimated values available at: https://www.cyberstates.org

2. Text available at: https://images-na.ssl-imagesamazon.com/images/G/01/Anything/test/images/usa/RFP_3._V516043504_.pdf

3. Text available at: https://www.amazon.com/b?ie=UTF8\&node=17044620011

4. Spatial map of bidding communities available at: https://reflect.github.io/amazon-hq2-proposals/

5. Equitable in terms of a focus on community benefits, as compared with other think tanks, such as the US Council on Competitiveness, which are primarily focused on the needs of firms

6. Available at: https://www.goodjobsfirst.org/publications

\section{REFERENCES}

Anguelov, N. (2014). "Double" Competition for FDI in the United States: Is It Worth It? In Policy and Political Theory in Trade Practice: Multinational Corporations and Global Governments (pp. 91-112). New York, NY: Palgrave Pivot.

Atkinson, R. D. (2004). The Past and Future of America's Economy: Long Waves of Innovation That Power Cycles of Growth. Cambridge, MA: Edward Elgar Publishing.

Barkley, D. L., \& Henry, M. S. (1997). Rural industrial development: to cluster or not to cluster? Review of Agricultural Economics, 19(2), 308-325.

Barnet, R. J. (1996). The end of jobs. Bulletin of Science, Technology \& Society, 16(4), 183-188.

Bartik, T. J. (2018). 'But For' percentages for economic development incentives: What percentage estimates are plausible based on the research literature? Research Paper \#18-289, Upjohn Institute for Employment Research. Retrieved from https://research.upjohn.org/cgi/viewcontent.cgi?article=1307\&context=up_workingpapers

Belderbos, R., Lykogianni, E., \& Veugelers, R. (2008). Strategic R\&D location by multinational firms: spillovers, technology sourcing, and competition. Journal of Economics \& Management Strategy, 17(3), 759-779.

Bollinger, C. R., \& Ihlanfeldt, K. R. (2003). The intraurban spatial distribution of employment: which government interventions make a difference? Journal of Urban Economics, 53(3), 396-412.

Bondonio, D., \& Greenbaum, R. T. (2007). Do local tax incentives affect economic growth? What mean impacts miss in the analysis of enterprise zone policies. Regional Science and Urban Economics, 37(1), 121-136.

Briguglio, L., Cordina, G., Farrugia, N., \& Vella, S. (2006). Conceptualizing and measuring economic resilience. Building the Economic Resilience of Small States. Malta: Islands and Small States Institute of the University of Malta and London: Commonwealth Secretariat, 265-288.

Byrnes, N., \& Cowan, C. (2007). 'The high cost of wooing Google. Business Week, 23.

Davis, C., Davis, K., Gardner, M., Heimovitz, H., Johnson, S., McIntyre, R. S., ...Wiehe, M. (2015). Who Pays: A Distributional Analysis of the Tax Systems in All 50 States, $5^{\text {th }}$ Edition. Washington, DC: Institute on Taxation \& Economic Policy. Retrieved from www.itep.org/pdf/whopaysreport.pdf.

Díez-Vial, I., \& Fernández-Olmos, M. (2015). Knowledge spillovers in science and technology parks: how can firms benefit most? The Journal of Technology Transfer, 40(1), 70-84.

Faulk, D. (2002). Do state economic development incentives create jobs? An analysis of state employment tax credits. National Tax Journal, 263-280.

Florida, R. (2019). The Rise of the Creative Class. New York: Basic books.

Francia, P. L., Green, J. C., Herrnson, P. S., Wilcox, C., \& Powell, L. W. (2003). The Financiers of Congressional Elections: Investors, Ideologues, and Intimates. New York, NY: Columbia University Press.

Garnsey, E., \& McGlade, J. (Eds.). (2006). Complexity and Co-Evolution: Continuity and Change in Socio-Economic Systems. Cambridge, MA: Edward Elgar Publishing. 
Glass, I. (2011, May 13). This American Life: Episode 435: "How to Create a Job." Transcript. Retrieved August 25, 2017, from www.thisamericanlife.org/radio-archives/episode/435/transcript

Gordon, S. C., Hafer, C., \& Landa, D. (2007). Consumption or investment? On motivations for political giving. The Journal of Politics, 69(4), 1057-1072.

Greenstone, M., \& Moretti, E. (2003). Bidding for industrial plants: Does winning a "million-dollar plant” increase welfare? National Bureau of Economic Research Working Paper, No. 9844. Washington, DC. Retrieved from www.nber.org/papers/w9844.

Grieco, J. M. (1982). Between Dependency and Autonomy: India's Experience with the International Computer Industry. International Organization, 36, 609-632.

Gropp, M. R., \& Kostial, M. K. (2000). The disappearing tax base: is foreign direct investment (FDI) eroding corporate income taxes? Working Paper No. 0-173. Washington, DC: International Monetary Fund.

Gura, D. (2012, November 13). Google search in North Carolina: Jobs. Marketplace.org. Retrieved from www.marketplace.org/topics/tech/google-search-north-carolina-jobs

Hagan, K. (2015, May 31). Commentary: Keep Hillsborough and Florida in film game by continuing tax credit program. Tampa Tribune.

Hanson, A., \& Rohlin, S. (2011). Do location-based tax incentives attract new business establishments? Journal of Regional Science, 51(3), 427-449.

Hicks, M. J., \& LaFaive, M. (2011). The influence of targeted economic development tax incentives on county economic growth: Evidence from Michigan's MEGA credits. Economic Development Quarterly, 25(2), 193-205.

Hickey, J. (2013). Federal and state legislative moves to boost competitiveness \& business climate. Area Development. Retrieved from www.areadevelopment.com/EconomicsGovernmentPolicy/Q12013/state-federal-legislation-boost-business-climate-2727261.shtml

Hill, E., Wial, H., \& Wolman, H. (2008). Exploring regional economic resilience. Working Paper \# 04. Washington, DC: Institute of Urban and Regional Development.

Holloway, S. R., \& Wheeler, J. O. (1991). Corporate headquarters relocation and changes in metropolitan corporate dominance, 1980-1987. Economic Geography, 67(1), 54-74.

Isaksson, O. H., Simeth, M., \& Seifert, R. W. (2016). Knowledge spillovers in the supply chain: Evidence from the high tech sectors. Research Policy, 45(3), 699-706.

Jensen, N. M. (2017a, April-June). The effect of economic development incentives and clawback provisions on job creation: A pre-registered evaluation of Maryland and Virginia programs. Research and Politics, 1-8.

Jensen, N. (2017b). Job creation and firm-specific location incentives. Journal of Public Policy, 37(1), $85-112$.

Jensen, N. (2017c). Exit options in firm-government negotiations: an evaluation of the Texas chapter 313 program. Washington Center for Equitable Growth Working Paper series. Washington, DC: Washington Center for Equitable Growth.

Jensen, N. M., \& Malesky, E. J. (2018). Incentives to Pander: How Politicians Use Corporate Welfare for Political Gain. Cambridge, UK: Cambridge University Press.

Jensen, N. M., Malesky, E. J., Medina, M., \& Ozdemir, U. (2014). Pass the bucks: Investment incentives as political credit-claiming devices. International Studies Quarterly, 58, 433-447.

Jensen, N. M., Malesky, E. J., \& Walsh, M. (2015). Competing for global capital or local voters? The politics of business location incentives. Public Choice, 164(3-4), 331-356.

Johnson, W. (2015, April 26). Ferguson's Fortune 500 company: Why the Missouri city - despite hosting a multinational corporation - relied on municipal fees and fines to extract revenue from its poorest residents. Atlantic.

Klepper, S. (1996). Entry, exit, growth, and innovation over the product life cycle. The American Economic Review, 562-583.

Klier, T., \& Testa, W. (2002). Location trends of large company headquarters during the 1990s. Economic Perspectives, 26(2), 12-26. 
Kline, P., \& Moretti, E. (2014). People, places, and public policy: some simple welfare economics of local economic development programs. Annual Review of Economics, 6, 629-662.

Kogut, B. M. (Ed.). (2003). The Global Internet Economy. Boston, MA: MIT Press.

LeRoy, G., Fryberger, C., Tarczynska, K., Cafcas, T., Bird, E., \& Mattera, P. (2015). Shortchanging small business: How big businesses dominate state economic development incentives. Washington, DC:

Good Jobs First. Retrieved from https://papers.ssrn.com/sol3/papers.cfm?abstract_id=2771463

Loveman, G. W., \& Gabarro, J. J. (1991). The managerial implications of changing work force demographics: A scoping study. Human Resource Management, 30(1), 7-29.

Markle, K. S., \& Shackelford, D. A. (2014). The impact of headquarter and subsidiary locations on multinationals' effective tax rates. Tax Policy and the Economy, 28(1), 33-62.

Martin, R. (2010). Roepke lecture in economic geography-rethinking regional path dependence: beyond lock-in to evolution. Economic Geography, 86(1), 1-27.

Martinez-Fernandez, C., Audirac, I., Fol, S., \& Cunningham-Sabot, E. (2012). Shrinking cities: Urban challenges of globalization. International Journal of Urban and Regional Research, 36(2), 213225.

Markusen, A. (1996). Sticky places in slippery space: a typology of industrial districts. Economic Geography, 72(3), 293-313.

Mattera, P., Tarczynska, K., \& LeRoy, G. (2013). Megadeals: The largest economic development subsidy packages ever awarded by state and local governments in the United States. Retrieved from www.goodjobsfirst.org/sites/default/files/docs/pdf/megadeals_report.pdf

Mattera, P., Tarczynska, K., Mcllvaine, L., Cafcas, T., \& LeRoy, G. (2012). Paying taxes to their bosses: How a growing number of states subsidize companies with the withholding taxes of workers. Retrieved from www.goodjobsfirst.org/sites/default/files/docs/pdf/taxestotheboss.pdf

Miller, R. (2013, April 19). Google expands in North Carolina, Will Boost Renewables. Data Center Knowledge. Retrieved from www.datacenterknowledge.com/archives/2013/04/19/googleexpands-in-north-carolina-will-boost-renewables/.

Karayel, S. (2017). Power of automotive supplier cluster: the case of BMW in South Carolina. European Scientific Journal, 13(4), 87-103.

Koven, S. G., \& Koven, A. C. (2018). Growth, Decline, and Regeneration in Large Cities: A Case Study Approach. London: Routledge.

Pacewicz, J. (2012). Tax increment financing, economic development professionals and the financialization of urban politics. Socio-Economic Review, 11(3), 413-440.

Pellow, D. N., \& Park, L. S. H. (2002). The Silicon Valley of dreams: Environmental injustice, Immigrant Workers, and the High-tech Global Economy. New York: NYU Press.

Pendall, R., Foster, K. A., \& Cowell, M. (2010). Resilience and regions: building understanding of the metaphor. Cambridge Journal of Regions, Economy and Society, 3(1), 71-84.

Pries, L. (2006). Cost competition or innovation competition? Lessons from the case of the BMW plant location in Leipzig, Germany. Transfer: European Review of Labour and Research, 12(1), 11-29.

Prillaman, S. A., \& Meier, K. J. (2014). Taxes, incentives, and economic growth: Assessing the impact of pro-business taxes on US state economies. The Journal of Politics, 76(2), 364-379.

Rose, A., \& Liao, S. Y. (2005). Modeling regional economic resilience to disasters: A computable general equilibrium analysis of water service disruptions. Journal of Regional Science, 45(1), 75-112.

Saxenian, A. (1983). The urban contradictions of Silicon Valley: regional growth and the restructuring of the semiconductor industry. International Journal of Urban and Regional Research, 7(2), 237262.

Saxenian, A. (1990). Regional networks and the resurgence of Silicon Valley. California Management Review, 33(1), 89-112.

Simmie, J., \& Martin, R. (2010). The economic resilience of regions: towards an evolutionary approach. Cambridge Journal of Regions, Economy and Society, 3(1), 27-43.

Story, L. (2012, December 1). As Companies Seek Tax Deals, Governments Pay High Price. New York Times.

50 Journal of Strategic Innovation and Sustainability Vol. 15(1) 2020 
Sullivan, D., \& Green, G. (1999). Business subsidies and municipal controls. Journal of Urban Affairs, 21(3), 267-279.

Stevens, L., Vielkind, J., \& Honan, K. (2019, February 14). Amazon cancels HQ2 plans in New York City. The Wall Street Journal.

Tarczynska, T. (2016). Money lost to the cloud: How data centers benefit from state and local government subsidies. Good Jobs First, Washington, DC. Retrieved from http://www.goodjobsfirst.org/sites/default/files/docs/pdf/datacenters.pdf

Thomas, K. (2010). Investment Incentives and the Global Competition for Capital. New York: Springer.

Vernon, R. (1979). The product cycle hypothesis in a new international environment. Oxford Bulletin of Economics and Statistics, 41(4), 255-267.

Venables, A. (2006). Shifts in economic geography and their causes. Centre for Economic Performance, London, UK: London School of Economics and Political Science.

Walker, R., \& Greenstreet, D. (1991). The effect of government incentives and assistance on location and job growth in manufacturing. Regional Studies, 25, 13-30.

Wilson, J. D. (1986). A theory of interregional tax competition. Journal of Urban Economics, 19(3), 296315.

Zee, H. H., Stotsky, J. G., \& Ley, E. (2002). Tax incentives for business investment: a primer for policy makers in developing countries. World Development, 30(9), 1497-1516. 


\section{APPENDIX}

\section{LIST OF THE ANALYZED DEALS}

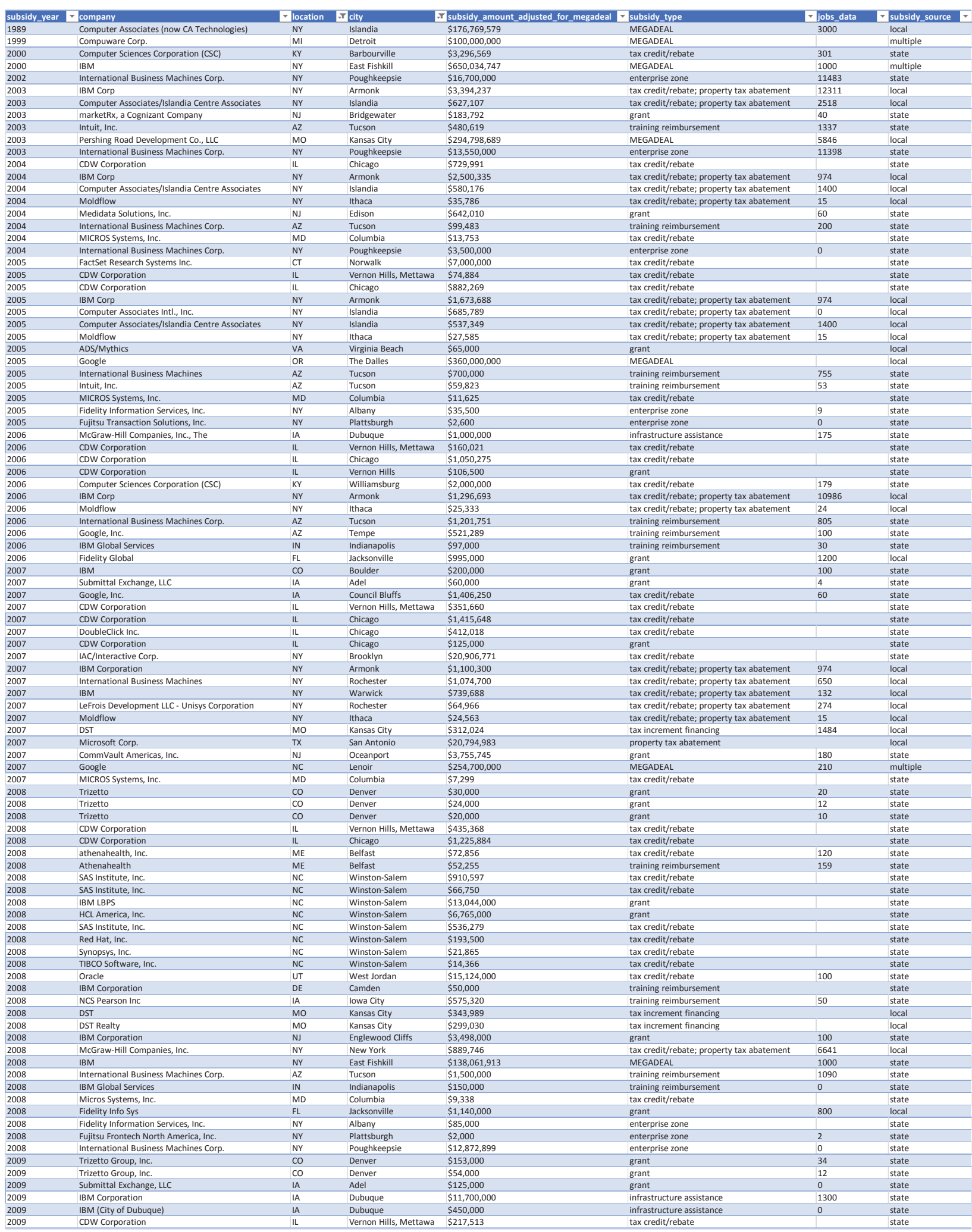

52 Journal of Strategic Innovation and Sustainability Vol. 15(1) 2020 


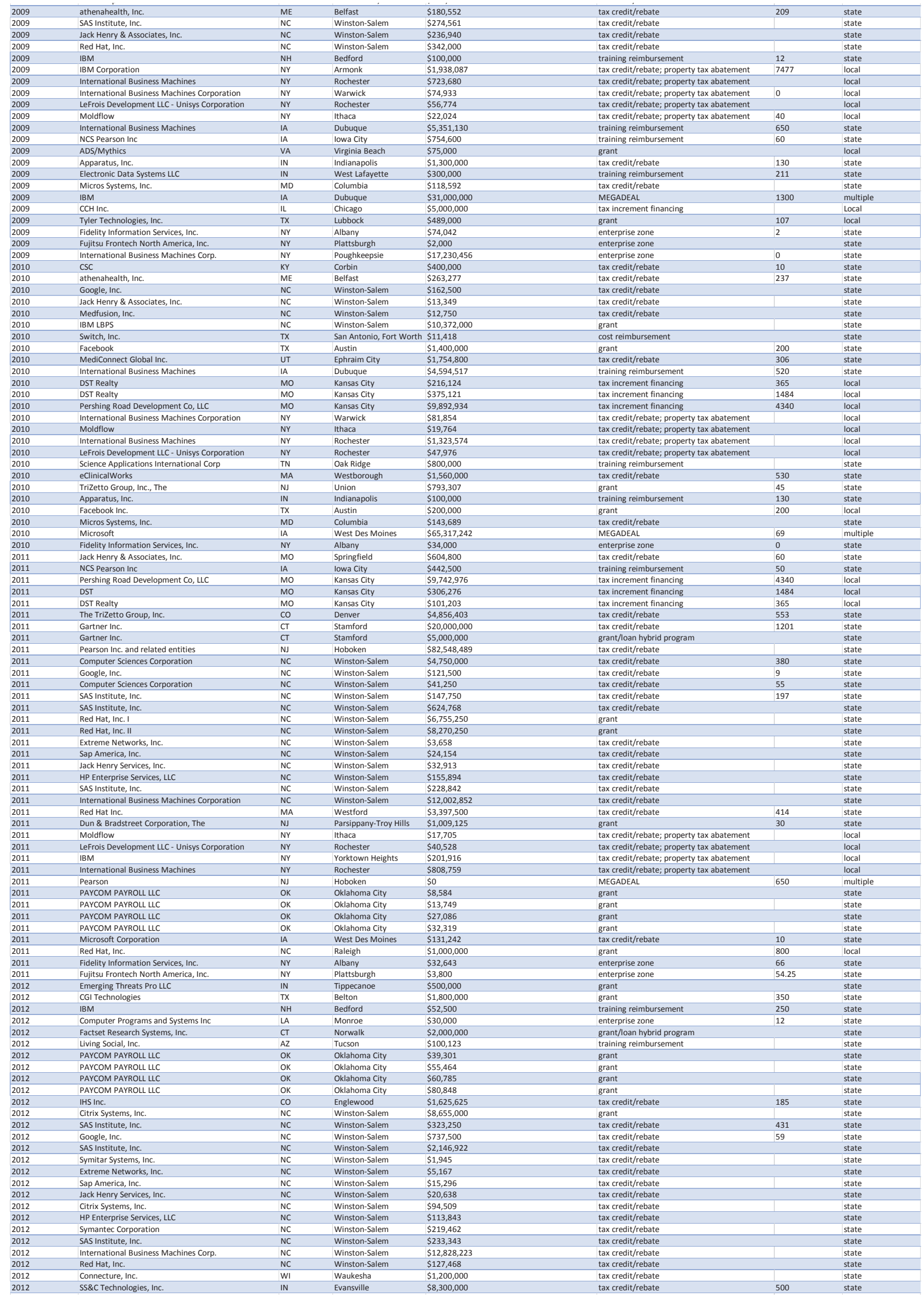

Journal of Strategic Innovation and Sustainability Vol. 15(1) 202053 


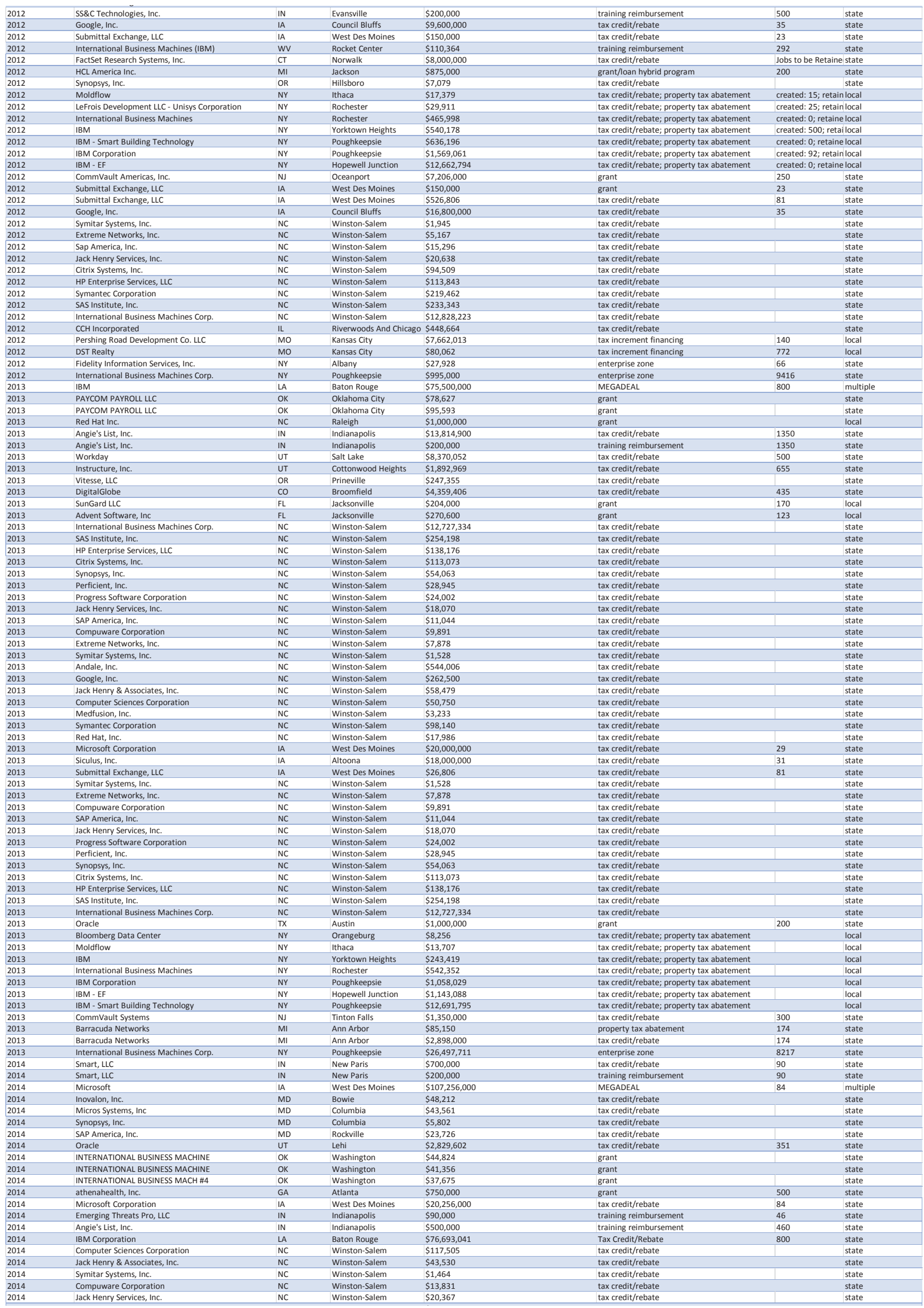

54 Journal of Strategic Innovation and Sustainability Vol. 15(1) 2020 


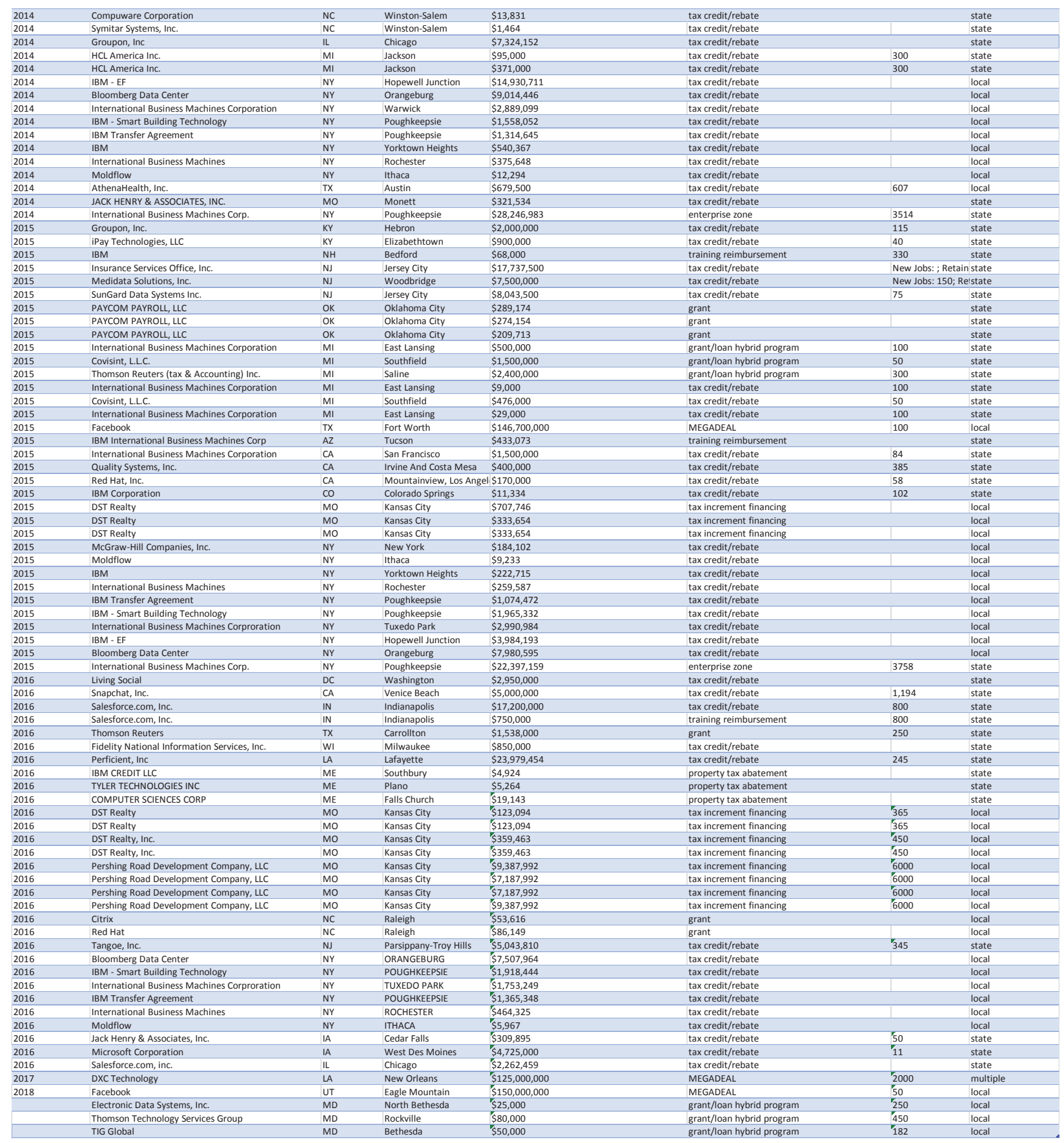

